\title{
Firm-Level Corruption in Vietnam
}

Rand, John; Tarp, Finn

Published in:

Economic Development and Cultural Change

Publication date:

2012

Citation for published version $(A P A)$ :

Rand, J., \& Tarp, F. (2012). Firm-Level Corruption in Vietnam. Economic Development and Cultural Change, 60(3). 


\title{
Firm-Level Corruption in Vietnam
}

\author{
JOHN RAND \\ University of Copenhagen
}

\section{FINN TARP}

\section{University of Copenhagen and UNU-WIDER}

\section{Introduction}

The fight against corruption has received increasing public attention in Vietnam, especially after 2005, when a new law on corruption was passed. ${ }^{1}$ The establishment of the National Anti-Corruption Committee in 2006, in charge of overseeing the handling of complaints and accusations of corruption, signals political commitment to take corruption seriously, ${ }^{2}$ and Vietnamese newspapers have extended their coverage of corruption very considerably. ${ }^{3}$ The increasing focus on combating bribes has also led to a series of punitive actions against corrupt public officials (bribe takers) and bribe-providing firms (bribe givers). Finally, reported bribe cases cover both larger-scale corruption scandals (e.g., bribes paid by bigger firms to public officials often in exchange for a government contract) and minor bribe incidents (bribe payments to police officers and registration offices) involving smaller firms and individuals.

Nevertheless, corrupt behavior remains widespread in the Vietnamese business environment, and it is generally agreed that corruption is costly because of the associated efficiency losses in the allocation of resources related to the distorting and uncertain nature of the corruption "tax" (Fisman and Svensson

We are grateful for most helpful editorial advice and excellent reviewer comments. We also acknowledge productive and stimulating collaboration with the survey teams from the Vietnamese Institute of Labor Science and Social Affairs and staff at the Central Institute for Economic Management. Financial support from Danida is appreciated. The usual caveats apply.

${ }^{1}$ Subsequently, Vietnam ratified the UN convention against corruption in 2009.

${ }^{2}$ Prior to the establishment of the National Anti-Corruption Committee, a series of provinces established similar entities to help fight corruption.

3 To substantiate this, we have reviewed the newspaper articles written in English from (i) Vietnam News available at http://www.vietnamnews.vnagency.com.vn, (ii) Thanh Nien News available at http://www.thanhniennews.com/Pages/default.aspx, and (iii) VietnamNet available at http://www .english.vietnamnet.vn. Case studies in McKinley (2008) suggest that the role of the press in combating corruption has increased over time and that the press in Ho Chi Minh City has been allowed relatively more freedom of speech than in the northern provinces (including Hanoi). 
2007). A recent Investment Climate Assessment survey (2005) for Vietnam suggests that two-thirds of firms incur informal payments as part of running their business. Moreover, $79 \%$ are expected to give "gifts" in meetings with tax officials and $40 \%$ feel it is necessary to pay bribes in order to secure government contracts. The Provincial Competitiveness Index (PCI; VNCI 2008) confirms that bribes to public officials remain a major challenge when doing business, and both the frequency and size of bribes have remained at relatively high levels despite recent comprehensive public administration reforms aimed at reducing corruption. ${ }^{4}$

This background and context motivate the present article. Our overall aim is to come better to grips with the nature, evolution, and potential impact of bribe-paying behavior with a view to identifying relevant policy action. The basic approach involves putting together an in-depth description of bribepaying behavior based on a unique balanced panel data set with information on 1,659 small- and medium-sized enterprises (SMEs) in 10 provinces of Vietnam in 2005 and 2007. We show that bribe incidence is highly associated with firm-level differences in visibility, sunk costs, and ability to pay. The same goes for interaction with public officials when the state supplies inputs and government assistance, but not so when the state acts as a customer and firms deal with customs. The impact of being subject to inspection is, on the basis of our analysis, less clear. However, formal registration is positively correlated with bribe incidence, so "visibility" in this sense seems to dominate the "bribes-to-hide" effect in determining corruption. It also emerges that the incidence of corruption and the magnitude of payments are driven by quite distinct processes.

Turning to the panel dimension of our data, we are able to tune in to trends in corruption and try to disentangle the reasons for the significant observed decrease in bribe incidence between 2005 and 2007. We ask how the determinants of bribes have changed between the two years and apply a nonlinear version of the Blinder-Oaxaca decomposition approach as a way to wring more information out of the data while still framing it as a determinants analysis. Our analysis suggests that the coefficients effect dominates. This implies that the decrease in bribe incidence is related to behavioral changes among firms, and these behavioral changes seem to be associated with policy initiatives to improve law enforcement and increased media focus on punitive actions against corruption.

The remainder of this article is organized as follows. Section II provides

\footnotetext{
${ }^{4}$ Public administration reforms have included both administrative simplification of procedures and regulations and an increase in salaries and quality of civil servants.
} 
further background and sets out the analytical point of departure. Descriptive statistics on bribe payments and potential determinants of bribing behavior are also provided. Section III presents econometric results, and Section IV concludes that both general and targeted policy measures should be relied on to combat corruption effectively.

\section{Data and Analytical Framework}

\section{A. Data}

The two SME surveys on which we rely in this article were conducted in 2005 and 2007. ${ }^{5}$ Both surveys covered around 2,600 enterprises in 10 provinces (Ho Chi Minh City [HCMC], Hanoi, Hai Phong, Long An, Ha Tay, Quang Nam, Phu Tho, Nghe An, Khanh Hoa, and Lam Dong). In both years and all areas covered by the surveys, samples were stratified by ownership form to ensure that all types of nonstate enterprises, including both officially registered (with a business registration license) formal household, private, cooperative, limited-liability, joint-stock enterprises, and nonofficial (informal) household firms, were represented. For reasons of implementation, the surveys were confined to specific areas in each province/city. Subsequently, stratified random samples were drawn from a consolidated list of formal enterprises and an onsite random selection of informal firms. ${ }^{6}$ While the sampling was adjusted over time to accommodate the rapidly changing business environment in Vietnam, other aspects, including the questionnaires, were maintained virtually identical. ${ }^{7}$ After cleaning the data and checking consistency of time-invariant variables between the two survey rounds, we were left with a balanced panel

5 The World Bank SME Department currently operates with three groups of SMEs: micro, smallscale, and medium-scale firms. Micro enterprises have between 1 and 10 employees, small-scale enterprises between 11 and 50 employees, and medium-size enterprises between 51 and 300 employees. These definitions are broadly accepted by the Vietnamese government (see government decree no. 90/2001/CP-ND, "Supporting for Development of Small and Medium Enterprises," http://www.unido.org/fileadmin/import/40748_DecreeSME2001.pdf). In what follows, we follow these definitions noting that a few firms sampled at the time of the interview had grown beyond 300 employees. They are therefore categorized here as large.

${ }^{6}$ Appropriate weights for formal household firms are difficult to obtain as the 2007 Establishment Census is yet to be finalized. The household business sector has experienced enormous changes during the period under study, and it is not reliable to use the Establishment Census from 2002 (General Statistics Office 2004) to generate appropriate weights. Moreover, the Establishment Census covers only registered individual household business establishments, which have a business license issued by a District Business Register Office. The nonregistered (informal) household firms in our sample have not obtained such a license and are therefore not well covered in official census statistics. Since no reliable household firm population information exists for 2005 and 2007, we find it most appropriate to report unweighted estimates in the analysis.

${ }^{7}$ Full details on the surveys and sampling procedures can be found in CIEM (2007, 2009) and at the following website: http://www.econ.ku.dk/rand. 
TABLE 1

BRIBE INCIDENCE OVERVIEW

\begin{tabular}{lccccr}
\hline & \multicolumn{4}{c}{2007} & \\
\cline { 2 - 4 } 2005 & No & \multicolumn{2}{c}{ Yes } & Total \\
\hline No & 890 & $(85)$ & 156 & $(15)$ & 1,046 \\
& $(70)$ & $(40)$ & $(63)$ \\
Yes & 383 & $(62)$ & 230 & $(38)$ & 613 \\
& $(30)$ & $(60)$ & $(37)$ \\
Total & 1,273 & $(77)$ & 386 & $(23)$ & 1,659 \\
\hline
\end{tabular}

Note. Entries are the numbers of enterprises (percentages are in parentheses).

of 1,659 firm observations in each year. It is especially a lack of financial accounts that reduced the number of observations. ${ }^{8}$

\section{B. Informal Payments}

Before turning to our analytical point of departure and description of variables associated with the incidence of informal payments, we briefly discuss our main variable of interest, that is, bribe incidence. Table 1 shows the number of enterprises that paid bribes in 2005 and 2007. Some 37\% of firms provided an informal payment in 2005, a share that fell substantially to $23 \%$ in 2007.

Significant variation in bribe payments is also observed across firms over time. Only $38 \%$ of the bribe-paying firms and $14 \%$ of the entire sample paid bribes in both periods. Also noticeable is that $15 \%$ of the 1,046 firms that did not pay bribes in 2005 did incur an informal payment in 2007. This underlines that a very significant share of firms have at some point found it necessary to pay bribes.

Enterprise owners and managers in our survey were asked about the main purpose for paying bribes. Their responses indicate that the following reasons are common: (i) to get connected to public services (29.9\%), (ii) to deal with taxes and tax collectors $(21.3 \%)$, and (iii) to gain government contracts $(15.5 \%)$. "Other reasons" $(26.6 \%)$ are also widespread as a group, whereas to get licenses and permits (4.3\%) and to deal with customs (2.3\%) are less frequent.

Firms were asked as well to provide information on the size of the informal payment. Table 2 links these data to the purpose of the bribes and the size distribution of firms. It is clear that bribes paid to gain government contracts are, on average, the largest as measured relative to firm revenues. Bribes paid to deal with taxes and tax collectors are also relatively sizable, whereas the most frequent type of payment (i.e., to get connected to public services)

\footnotetext{
${ }^{8}$ The two surveys cover annual financial accounts information for the period 2003-7.
} 
TABLE 2

AVERAGE SIZE OF INFORMAL PAYMENTS

\begin{tabular}{|c|c|c|c|}
\hline & Observations & $\begin{array}{c}\text { Bribe Amount } \\
\text { (\% of Total } \\
\text { Revenues) }\end{array}$ & $\begin{array}{c}\% \text { of Bribes } \\
\text { Paid by } \\
\text { Medium/Larger } \\
\text { Firms }\end{array}$ \\
\hline To get connected to public services & 298 & .30 & 10 \\
\hline To get licenses and permits & 43 & .56 & 7 \\
\hline To deal with taxes and tax collectors & 213 & .74 & 10 \\
\hline To gain government contracts & 155 & 1.09 & 15 \\
\hline To deal with customs & 23 & .33 & 61 \\
\hline Other reasons & 266 & .38 & 0 \\
\hline Total & 998 & .55 & 13 \\
\hline
\end{tabular}

involves payments that are relatively smaller in average size. Also, while the share of bribes paid by medium/larger firms is generally below $15 \%$, this share is no less than $61 \%$ when dealing with customs. Note also that 266 firm answers are in the other reasons category and that all these firms are micro and small firms. This suggests that the specific reasons for bribe behavior among the bigger firms in our sample are clearly revealed.

The enterprise interviews also imply that companies tend to accept corrupt bureaucratic practices (if facing a request for a bribe) and also that few firms (owners and managers) consider bribe payments a serious constraint to business development. This is in line with anecdotal evidence in Segon and Booth (2010) that payments are relatively easy to internalize. Along the same lines, Sato (2009) concludes that corruption is not perceived as particularly destructive and that bribes are more of a customary business practice in Vietnam. There is, however, reason to be cautious here. Our data show that $62 \%$ of bribe-paying firms (not reported) say that they never know in advance how much they have to pay in bribes. This is significantly above the average of 9\% reported in Wu (2009) based on data from the World Business Environment Survey covering 1,867 firms in 12 Asian countries. Our data therefore suggest that the potential negative "distorting" impact of bribes might well be quite high in Vietnam because of their uncertain and random nature.

\section{Analytical Point of Departure}

Our theoretical point of departure in studying the incidence and level of bribes in Vietnam is the Shleifer and Vishny $(1993,1994)$ framework, which was also adopted by Svensson (2003) and Fisman and Svensson (2007). Moreover, the recent literature on firm-level determinants of informality (Dabla-Norris, Gradstein, and Inchauste 2008; McKenzie and Sakho 2010) helped in formulating the empirical specifications of the link between bribe incidence and firm informality. Accordingly, we start out in a situation in which a firm with 
some probability faces a public official, who extracts bribes that need to be paid for the business to run smoothly. The corrupt public official may take actions that can either benefit or harm the firm. The beneficial action could be a lax attitude toward implementing rules and regulations. That is, a corrupt public official may be ready to work the system in favor of the firm so that it obtains information, gets business orders, and/or remains informal, resulting in increased firm profit (referred to as the "speed-money argument"). ${ }^{9}$ Harmful actions, on the other hand, stem from a discretionary power to harass the firm, which may lead to extra costs and even firm closure. The threat of harassment implies that a corrupt public official has some leverage in extracting bribes.

If the corrupt official has discretionary power in implementing, executing, and enforcing rules relevant to the firm's doing business, this will affect the threat point in the negotiation between the official and the firm. For example, a firm with full control rights can avoid paying bribes without significant impact on business operations. When public officials maintain some control over firms (through regulation), firm bargaining power will be reduced and firms may end up paying a bribe. Corrupt officials will in theory act as perfect price discriminators, extracting the highest possible bribe subject to the constraints that they may get caught and that the firm might exit. Accordingly, the probability of making a bribe payment and the amount paid will depend on a firm's "ability to pay" and the outside option of not paying.

Turning now to our list of potential bribe determinants, we observe that firms differ in several aspects affecting profitability and choice of technology. These firm characteristics determine a firm's ability to pay bribes and the cost of reallocating its business elsewhere. We use profits per employee as a proxy for firm ability or willingness to pay. Firm refusal power (i.e., the outside option) is proxied by the capital-labor $(\mathrm{KL})$ ratio since capital is at least partly sunk. Technology with a low sunk cost component (low KL ratio) will, ceteris paribus, strengthen the firm's bargaining position. Exiting becomes more profitable or less costly. As a result, the public official will demand a lower bribe. Summary statistics on both the profit and KL variables are provided in table 3, and we note that both mean profits per employee and the KL ratio went up from 2005 to 2007.

As in Svensson (2003), we hypothesize that firm "exposure/visibility" and the degree of interaction with public officials will influence bribe incidence.

\footnotetext{
9 Firms also affect bribe incidence. Firms benefiting the most from services provided by public officials will be more likely to offer bribes for easier access to a given service. As mentioned by Clarke and $\mathrm{Xu}$ (2004), this may lead to public services being allocated according to the value that different enterprises place on the particular services, with bribes acting as an efficient discrimination mechanism.
} 
TABLE 3

SUMMARY STATISTICS

\begin{tabular}{|c|c|c|c|c|c|c|}
\hline & \multicolumn{2}{|c|}{ Total } & \multicolumn{2}{|c|}{2005} & \multicolumn{2}{|c|}{2007} \\
\hline & Mean & SD & Mean & SD & Mean & SD \\
\hline Firm size (log) & 1.849 & 1.077 & 1.876 & 1.068 & 1.821 & 1.086 \\
\hline Micro & .689 & .463 & .676 & .468 & .701 & .458 \\
\hline Small & .256 & .437 & .267 & .443 & .246 & .431 \\
\hline Medium & .052 & .222 & .055 & .228 & .049 & .216 \\
\hline Large & .003 & .055 & .002 & .042 & .004 & .065 \\
\hline KL ratio (log) & 4.194 & 1.221 & 4.066 & 1.205 & 4.322 & 1.224 \\
\hline Profit per employee (log) & 2.310 & .866 & 2.184 & .842 & 2.437 & .871 \\
\hline State customer & .145 & .352 & .145 & .352 & .145 & .352 \\
\hline State supplier & .076 & .264 & .075 & .264 & .076 & .265 \\
\hline Trade & .058 & .234 & .061 & .240 & .054 & .227 \\
\hline Government assistance & .269 & .444 & .295 & .456 & .244 & .429 \\
\hline Inspections & .502 & .500 & .448 & .497 & .556 & .497 \\
\hline Not registered & .282 & .450 & .261 & .439 & .304 & .460 \\
\hline Total observations & 3,318 & & 1,659 & & 1,659 & \\
\hline
\end{tabular}

Note. Monetary figures are measured in real millions of Vietnamese dong.

We include two visibility proxies: firm size (number of employees) and an indicator variable for not being registered officially (informal). Larger firms are more visible, but enterprises without a formal business registration license can hide more easily from public officials and avoid bribes. However, we stress that informality may be associated with an opposite effect on bribe incidence. Firms may seek informality to avoid paying taxes. ${ }^{10}$ In this case, they offer the relevant public authorities an informal payment to maintain or gain the informal status and will continue doing so as long as the benefits from being informal (not paying taxes) exceed the informal payment provided. The net effect on the probability of paying bribes of not having a business registration license is therefore an empirical issue. ${ }^{11}$

Table 3 provides summary statistics for the two visibility variables. Around $69 \%$ of the firms in the cleaned sample are categorized as micro, $26 \%$ are small, and the remaining $5 \%$ are medium-sized firms. Some $28 \%$ of the firms are not registered at the district or provincial level, and we see a small increase (from $26 \%$ to $30 \%$ ) in the number of informal firms between the two surveys. We include as well in table 3 a series of variables that capture the degree to which firms interact directly with public officials. Hansen, Rand, and Tarp (2009) find that having the state sector or a state-owned enterprise (SOE) as a customer has a positive and well-determined effect on firm performance. It

\footnotetext{
${ }^{10}$ Svensson (2003) includes a "pay taxes" dummy as a control rights measure. In our data, informality (not registered) dominates the pay taxes indicator variable and is therefore excluded in this analysis.

${ }^{11}$ In the data we find that $94 \%$ of the firms not paying taxes (491 out of 523 firm observations) do not have a business registration license.
} 
may well be that the associated benefits are informally divided between the firm and the public official responsible for the firm/client contact. We also include an indicator variable capturing whether SOEs provide the firm with intermediate inputs necessary for production. Table 3 shows that $15 \%$ of firms have the state sector as a customer and only $8 \%$ of firms had an SOE as their main supplier of inputs. Compared with the figures for the 1990s in Hansen et al. (2009), this is a remarkable drop. However, this is as expected as statesector influence has been gradually reduced in Vietnam since the 1990s, including the privatization of SOEs.

Following Svensson (2003), we include as well an indicator variable for foreign trade (import of intermediates and/or export of products). ${ }^{12}$ From table 2 we have the number of firms paying bribes to deal with customs. When this information is combined with trade information (6\% of the sample trade internationally), it follows that $59 \%$ of firms engaging in international trade pay bribes. However, only $18 \%$ of the trading and bribe-paying companies pay the bribe to the customs authority. This makes it unclear a priori whether it is trade (and interaction with customs) or other firm characteristics of traders that increase the probability of providing informal payments. This issue is addressed in the results section.

Over the years, promotion of SMEs has been a central policy for the Vietnamese government. Government support to SMEs can be divided into two groups: financial and technical assistance. The former includes various forms of investment incentives and soft policy loans, and the latter basically consists of three subtypes of assistance: human resource training, export promotion initiatives, and quality and technology programs. ${ }^{13}$ While the share of firms receiving assistance from government authorities has fallen since the 1990s, table 3 shows that around $27 \%$ of firms received some kind of government assistance in 2005-7. This is in line with the focus of the Vietnamese government on promoting private-sector development. It also increases enterprise interaction with potentially corrupt public officials.

Besides increasing the interaction between public officials and firms, inspections impose a direct administrative cost on the enterprise (time use of management is strongly correlated with the number of compliance inspections).

\footnotetext{
12 The survey also provides information on the average amount of time used by customs to handle firm cargo: $78 \%$ of importing firms report that it takes 0-14 days to handle cargo, whereas $50 \%$ of exporters experience that it takes 14 days or less.

13 The data provide detailed information on the different kinds of government support. But for the purpose of this article, we aggregate the government support information into one indicator variable. For details about the effects of government support in Vietnam using these data, see Hansen et al. (2009).
} 
Table 3 shows that around $50 \%$ of enterprises have been inspected, increasing from $45 \%$ in 2005 to $56 \%$ in 2007.

We include three additional variables that may potentially influence bribe payments. They reflect legal ownership form, location, and the sector in which the firm operates. ${ }^{14}$ The reasons are as follows:

1. Household firms are often less formal than other firm types and subject to different legal requirements. Consequently, differences in legal structure are a potential source of variation in informal payments. ${ }^{15}$ Legal ownership form is modeled using a set of dummy variables that represent the specific legal form of the firm (household, private, collective/partnership, limited-liability, or joint-stock enterprise). Appendix table A1 shows that $76 \%$ of the firms surveyed are in the household category.

2. Nguyen et al. (2007) highlight that Vietnamese provinces are relatively autonomous and have implemented centrally planned initiatives with a different pace and enthusiasm. Consequently, bribe incidence may differ across locations. We model location using indicator variables representing each province. Some $37 \%$ of the firms are located in urban areas (HCMC, Hanoi, and Hai Phong).

3. Sector choice influences firms' relative position on the value-added ladder. This may in turn affect the perceived ability to pay bribes. Sector may also capture additional aspects of the sunk cost component of physical capital (bargaining power) addressed above. On the other hand, relatively specialized and capital-intensive sectors at the top of the value-added ladder may attract more corrupt public officials, thereby increasing the level of competition among these government representatives. The net effect of sector on bribe incidence is therefore indeterminate a priori. We include sector dummies (based on twodigit-level International Standard Industrial Classification [ISIC] codes) to control for sector effects. The three best-represented sectors in our sample are food processing (ISIC 15;29\%), fabricated metal products (ISIC 28; 17\%), and wood (ISIC 20; 10\%).

\footnotetext{
14 Appendix table A1 reports the summary statistics.

15 Note that in the case of Vietnam, household firms register at the district level, whereas the government administrative unit for sole proprietorships, partnerships, limited-liability companies, and joint-stock companies is at the province level. This means that legal ownership form may matter for the type of public official the firm potentially has to face.
} 


\section{Econometric Results}

We address two key issues in our econometric analysis. First, we investigate the association between the potential bribe determinants identified above and the probability of providing informal payments. In this process we also aim to uncover differences in bribe amounts across the bribe-paying firms. Second, we wish to explain the decrease in bribe incidence between 2005 and 2007 and use the nonlinear version of the Blinder-Oaxaca decomposition approach (described in Farlie [2005]) as a way to help "make the data speak."

\section{A. Understanding Bribe Incidence}

In table 4 we begin by reporting regression results from a pooled probit model (cols. 1, 2, 4, and 5) and a fixed-effects linear probability model (cols. 3 and 6) using contemporaneous measures of the potential determinants identified above. ${ }^{16}$ We note first that the time dummy included is negative and significant throughout table 4 . This is in line with our expectations about the impact of intensified political commitment to combat corruption, but great care needs to be exercised here. This is a conditional trend term that takes into account all the other changes that have taken place in the right-hand-side variables. We therefore return to the trend issue in Section III.B.

Second, the exposure/visibility variable represented by firm size is positive and well determined in all specifications. Larger firms are more likely to pay bribes. This is contrary to results reported by Clarke and Xu (2004) and Wu (2009) but is consistent with the fact that larger firms are more "visible" and "exposed" to demands from corrupt officials. Similarly, and third, the estimates representing a firm's "ability to pay" (profit per employee) are positive although not well determined in all specifications. So, visible and high-profit firms are in general more likely to pay bribes. On the other hand, a fourth observation is that the coefficients on the outside options (captured by the KL ratio) also have the expected positive sign and are statistically well determined throughout. This means that there is support in the data for our prior that firms' "defensive capability," that is, their bargaining power vis-à-vis corrupt officials, also matters.

Fifth, zooming in on the results in columns $4-6$, we note that adding "interaction with government" controls is in general very important when trying to come to grips with bribe incidence. ${ }^{17}$ However, the kind of interaction

\footnotetext{
16 We use within-survey lagged explanatory variables, meaning that bribe incidence in 2005 is regressed on explanatory variables reported observed in 2003/4. Appendix table A3 shows that results from regressing bribe incidence in 2007 on lagged explanatory variables (observations from 2005) are largely consistent with the results in table 4.

${ }_{17}$ The correlation matrix of government interaction controls is provided in app. table A2.
} 


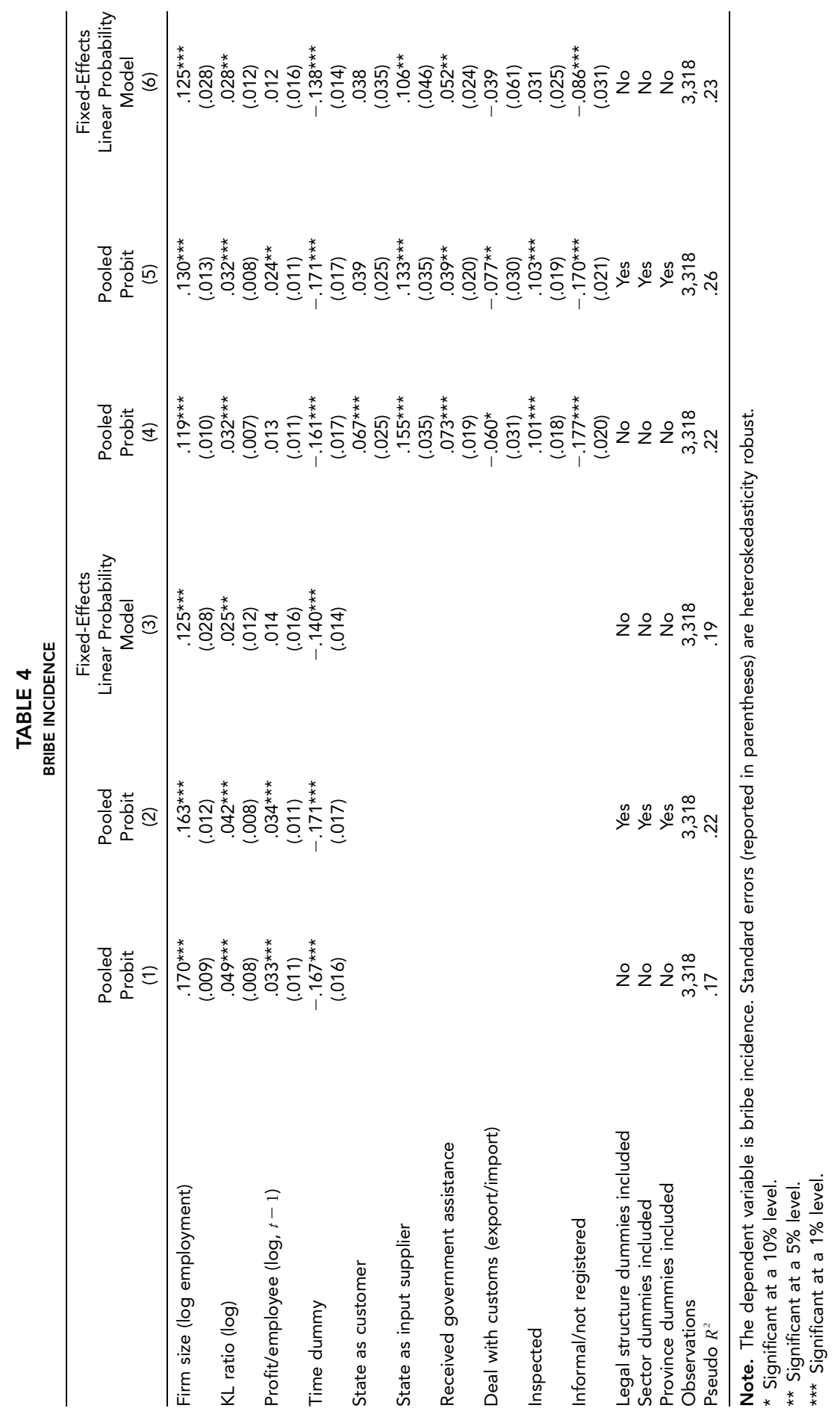

This content downloaded from 212.146.036.034 on August 01, 2016 05:26:49 AM All use subject to University of Chicago Press Terms and Conditions (http://www.journals.uchicago.edu/t-and-c). 
also seems to matter. In column 4 (not controlling for legal structure, sector, and location), we see that firms that have the state as a customer and firms that are supplied with inputs by SOEs are more likely to pay bribes. However, only the relatively large state supplier of inputs effect remains well determined when we control for legal structure, sector, and location (col. 5) and in the fixed-effects specification in column 6 . In contrast, the relatively small "state as customer effect" turns out not only smaller, but also insignificant, when the three controls are added. Government officials may seek to extract bribes through their control over the supply of state inputs, but the same may be the case in their influence over the supply of various kinds of government assistance such as management advice or access to credit. Our sixth observation is that such assistance does indeed often come at a "price" for the firms. Bribe incidence is significantly and positively associated with getting government assistance in all specifications, but this effect is considerably smaller than the input supply effect.

Our seventh result emerges from columns 4 and 5, which suggest that firms engaged in international trade and therefore interacting with customs authorities have a lower probability of paying bribes. This is opposite to the conclusion reached by Svensson (2003). However, this effect is not well determined in the fixed-effects specification in column 6. Moreover, firms trading internationally are found among the larger enterprises in the sample, and almost none of the micro firms import/export directly. Excluding micro enterprises from the sample results in an insignificant coefficient (not reported) on the "trade" indicator variable in columns 4 and 5. Overall, this suggests that dealing with customs is not an important determinant of bribe incidence.

In contrast, the eighth insight is that inspections and informal payments seem to go hand in hand. Firms that are inspected by public officials have a $10 \%$ higher probability of paying bribes than noninspected firms. This result is well determined in the pooled probit specifications, but when we control for unobserved heterogeneity in column 6, the impact of inspections on bribe incidence disappears. While only suggestive, the differences between the impact of dealing with customs and being subject to inspections are nevertheless interesting. The same goes for the observation that these two kinds of interaction with government officials have an insignificant impact in column 6 (as is the case for the state as customer interaction). This stands in clear contrast to the strong and well-determined impact on bribe incidence when interaction takes place either through the state as supplier of inputs or through the governance assistance channel.

Turning, ninth, to the potential impact of the degree of formalization, we note that informality is negatively associated with bribe incidence in all spec- 
ifications in table 4. This is contrary to the result obtained by Tenev et al. (2003) for Vietnam, but it is, on the other hand, perfectly in line with the hypothesis that hiding (and avoiding interaction with potentially corrupt public officials) is easier when the firm has informal status. ${ }^{18}$ It is also an indication that fighting corruption is likely to help further the badly needed process of formalizing Vietnamese SMEs. When formal, they will of course eventually be taxed, but the random and uncertain nature of corruption does arguably have more detrimental negative efficiency and growth impact than taxes at comparable levels (see Fisman and Svensson 2007).

Finally, and tenth, we find that firms in HCMC have a significantly lower probability of paying bribes (not reported). This is contrary to the findings in VNCI (2008), where HCMC is ranked at the bottom of the corruption index. Our result may therefore be surprising. However, it is consistent with the claim highlighted in Asia Times Online (November 16, 2006) that the high-profile corruption-busting campaign implemented in HCMC by the current president of Vietnam (Nguyen Minh Triet) in the early years of this century was highly effective. Triet was secretary of the Provincial Party Committee in HCMC, and he is widely recognized as an ardent anticorruption reformer.

We have now uncovered what our database suggests about the determinants of bribe incidence and turn next to looking at the magnitude of bribes actually paid. In appendix table $\mathrm{A} 4$, we report results of our attempt to explain the magnitude of bribe payments, relying on the explanatory variables used above and adding the firms' own responses to why they have paid bribes (see table 2). Two core sets of insights emerge. First, the results in table 2 are confirmed. Firms that pay bribes to get preferential tax benefits and to gain government contracts are indeed paying higher amounts (relative to total revenue) than firms that seek to get connected to public utilities, apply for licenses and permits, and deal with customs. Second, it is, as in Svensson (2003), clear that the incidence and the magnitude of bribes are driven by different processes. For example, while having the state as a customer is not a significant variable in explaining the incidence of bribe paying, bribes paid to get government contracts are relatively large.

\section{B. Change in Bribe Incidence}

We now turn to the significant decrease in bribe incidence between 2005 and 2007 , and in trying to uncover the underlying reasons, we make use of the

${ }_{18}$ To be clear, we do not claim here to have identified the impact of formalization itself due to potential firm-level endogeneity problems, which is why we have concentrated in this article on teasing out a qualitative description of bribe paying in Vietnam based on a unique data set. 
nonlinear version of the Blinder-Oaxaca decomposition method described in Farlie (2005). ${ }^{19}$ The Blinder-Oaxaca approach basically points to two different effects (or components). The first reflects how changes in the characteristics of firms over time affect the likelihood of paying bribes (referred to in what follows as the "characteristics effect"). The second is more secular in nature and captures the possibility that the effect of given firm characteristics on bribe behavior may change over time (the "coefficients effect"). In addition, a further decomposition is possible in which a third component is identified capturing the interaction between the characteristics and the coefficients effects.

Algebraically and asymptotically, the change in the outcome variable (bribe incidence) between 2005 and $2007\left(\bar{B}_{07}-\bar{B}_{05}\right)$ can be described by the following decomposition into two components:

$$
\begin{aligned}
\bar{B}_{07}-\bar{B}_{05}= & {\left[\Phi\left(\sum X_{07} \beta_{07}\right)-\Phi\left(\sum X_{05} \beta_{07}\right)\right] } \\
+ & {\left[\Phi\left(\sum X_{05} \beta_{07}\right)-\Phi\left(\sum X_{05} \beta_{05}\right)\right] }
\end{aligned}
$$

where $\Phi$ is the cumulative normal density function, $X_{07}$ and $X_{05}$ include the mean values of the explanatory variables used in the probit, and $\beta_{07}$ and $\beta_{05}$ contain the estimated coefficients for each year. The first and second parts of the right-hand side reflect, respectively, the characteristics and the coefficients effects.

Moreover, as shown in Sinning et al. (2008), when (1) is rearranged, the following threefold decomposition appears:

$$
\begin{aligned}
\bar{B}_{07}-\bar{B}_{05}= & {\left[\Phi\left(\sum X_{07} \beta_{05}\right)-\Phi\left(\sum X_{05} \beta_{05}\right)\right] } \\
+ & {\left[\Phi\left(\sum X_{05} \beta_{07}\right)-\Phi\left(\sum X_{05} \beta_{05}\right)\right] } \\
& +\left[\Phi\left(\sum X_{07} \beta_{07}\right)-\Phi\left(\sum X_{07} \beta_{05}\right)\right. \\
& \left.+\Phi\left(\sum X_{05} \beta_{07}\right)-\Phi\left(\sum X_{05} \beta_{05}\right)\right] .
\end{aligned}
$$

Let

$$
\begin{aligned}
& E=\Phi\left(\sum X_{07} \beta_{05}\right)-\Phi\left(\sum X_{05} \beta_{05}\right), \\
& C=\Phi\left(\sum X_{05} \beta_{07}\right)-\Phi\left(\sum X_{05} \beta_{05}\right), \\
& I=\Phi\left(\sum X_{07} \beta_{07}\right)-\Phi\left(\sum X_{07} \beta_{05}\right)+\Phi\left(\sum X_{05} \beta_{07}\right)-\Phi\left(\sum X_{05} \beta_{05}\right),
\end{aligned}
$$

and note that $E$ and $C$ represent, respectively, the endowment (or characteristics) and the coefficients effects, and $I$ captures their interaction. Results in

${ }^{19}$ For the implementation of the nonlinear Blinder-Oaxaca decomposition, we use the preprogrammed commands oaxaca and nldecompose developed for Stata by Jann (2008) and Sinning, Hahn, and Bauer (2008), respectively. 
TABLE 5

BLINDER-OAXACA DECOMPOSITION

\begin{tabular}{lccccc}
\hline & $(1)$ & $(2)$ & $(3)$ & $(4)$ & $(5)$ \\
\hline Characteristics (explained) effect & .002 & -.004 & .009 & .009 & -.004 \\
& $(.007)$ & $(.008)$ & $(.010)$ & $(.010)$ & $(.008)$ \\
Coefficients (unexplained) effect & $-.139^{\star \star \star}$ & $-.133^{\star \star \star}$ & $-.145^{\star \star \star}$ & $-.133^{\star \star \star}$ & $-.145^{\star \star \star}$ \\
& $(.014)$ & $(.015)$ & $(.015)$ & $(.015)$ & $(.015)$ \\
Interaction & & & & $-.013^{\star}$ & $.013^{\star}$ \\
& & & & $(.008)$ & $(.008)$ \\
Two- or threefold decomposition & Two & Two & Two & Three & Three \\
Reference group & Pooled & 2005 & 2007 & 2005 & 2007 \\
& including & coefficients coefficients coefficients coefficients \\
& time dummy & & & & \\
\hline
\end{tabular}

Note. Blinder-Oaxaca decomposition; 3,318 observations. The mean estimates in 2007 and 2005 are $.232(.010)$ and $.368(.012)$, respectively, yielding a predicted difference of $-.136(.016)$. Standard errors are reported in parentheses.

* Significant at a $10 \%$ level.

** Significant at a $5 \%$ level.

$\star \star \star$ Significant at a $1 \%$ level.

table 5 are reported using both a two- and a threefold decomposition approach. Since decomposition of nonlinear models shares the problem of the original Blinder-Oaxaca decomposition with regard to the choice of reference group, we report findings using both 2005 and 2007 coefficients as the reference group.

In our sample, the mean bribe incidence is 0.368 in 2005 and 0.232 in 2007. This yields a significant difference or gap of 0.137 . In columns $1-3$ of table 5, the bribe incidence gap is divided into a characteristics (explained) and a coefficients (unexplained) part. Columns 4 and 5 report a threefold decomposition, and the interaction effect is therefore included in addition to the endowment and coefficients effects. The decomposition output in table 5 suggests that most of the bribe incidence decrease of 13.6 percentage points is explained by differences in coefficients rather than by changes in observed characteristics (or interaction effects). This result emerges whether we use a two- or a threefold decomposition approach (and is largely independent of the choice of reference group). Accordingly, our results suggest that changing "preferences" in the Vietnamese business environment played the key role in lowering bribe incidence between 2005 and 2007.

The strong coefficients effect reflects both the negative time trend and changing slope coefficients for some covariates. This is illustrated in table 6 , which shows the total differential Blinder-Oaxaca decomposition. The top row reports the overall effects of characteristics, coefficients, and the interaction term in explaining the decrease in bribe incidence between 2005 and 2007, consistent with results reported in column 4 in table 5 . The remaining rows of table 6 depict the role of individual variables. 
TABLE 6

BLINDER-OAXACA DECOMPOSITION, SPECIFIC

\begin{tabular}{|c|c|c|c|}
\hline & $\begin{array}{c}\text { Characteristics } \\
\text { Effect } \\
\text { (1) }\end{array}$ & $\begin{array}{l}\text { Coefficients } \\
\text { Effect } \\
\text { (2) }\end{array}$ & $\begin{array}{l}\text { Interaction } \\
\text { Effect } \\
\text { (3) }\end{array}$ \\
\hline Aggregate effect & $\begin{array}{l}.009 \\
(.010)\end{array}$ & $\begin{array}{c}-.133^{\star \star \star} \\
(.015)\end{array}$ & $\begin{array}{c}-.013^{\star} \\
(.008)\end{array}$ \\
\hline Firm size (log employment) & $\begin{array}{c}-.006 \\
(.004)\end{array}$ & $\begin{array}{c}-.022 \\
(.032)\end{array}$ & $\begin{array}{l}.001 \\
(.001)\end{array}$ \\
\hline $\mathrm{KL}$ ratio (log) & $\begin{array}{l}.009^{\star \star \star} \\
(.003)\end{array}$ & $\begin{array}{c}-.054 \\
(.054)\end{array}$ & $\begin{array}{c}-.004 \\
(.004)\end{array}$ \\
\hline Profit/employee $(\log , t-1)$ & $\begin{array}{l}.005 \\
(.004)\end{array}$ & $\begin{array}{c}-.036 \\
(.040)\end{array}$ & $\begin{array}{c}-.005 \\
(.005)\end{array}$ \\
\hline State as customer & $\begin{array}{l}.000 \\
(.001)\end{array}$ & $\begin{array}{l}.002 \\
(.006)\end{array}$ & $\begin{array}{l}.000 \\
(.000)\end{array}$ \\
\hline State as input supplier & $\begin{array}{l}.000 \\
(.001)\end{array}$ & $\begin{array}{l}.002 \\
(.004)\end{array}$ & $\begin{array}{l}.000 \\
(.000)\end{array}$ \\
\hline Deal with customs (export/import) & $\begin{array}{c}.000 \\
(.000)\end{array}$ & $\begin{array}{r}-.008^{\star} \\
(.004)\end{array}$ & $\begin{array}{l}.001 \\
(.001)\end{array}$ \\
\hline Received government assistance & $\begin{array}{l}.003^{\star \star} \\
(.001)\end{array}$ & $\begin{array}{l}.004 \\
(.009)\end{array}$ & $\begin{array}{c}-.001 \\
(.002)\end{array}$ \\
\hline Inspected & $\begin{array}{l}.011^{\star \star \star} \\
(.003)\end{array}$ & $\begin{array}{c}-.011 \\
(.014)\end{array}$ & $\begin{array}{r}-.003 \\
(.004)\end{array}$ \\
\hline Informal/not registered & $\begin{array}{c}-.007^{\star \star} \\
(.003)\end{array}$ & $\begin{array}{c}-.012 \\
(.012)\end{array}$ & $\begin{array}{c}-.002 \\
(.002)\end{array}$ \\
\hline Constant & & $\begin{array}{l}.001 \\
(.074)\end{array}$ & \\
\hline
\end{tabular}

Note. Detailed Blinder-Oaxaca decomposition with reference to col. 4 in table 5; 3,318 observations. Standard errors are reported in parentheses. HCMC is the base category.

* Significant at a $10 \%$ level.

** Significant at a $5 \%$ level.

$\star \star \star$ Significant at a $1 \%$ level.

Starting with the specific characteristics effects, we conclude that the changes in bribe incidence have clear interpretable incentive effects on firms. From column 1 in table 6 we see that bribes can be seen as a tax on size (KL ratio), formality, and services received in the form of direct government assistance or through actions taken during inspections.

Given that almost $100 \%$ of the total effect can be explained by changes in behavioral response to characteristics between the two surveys, we focus on the coefficients effect. Of an aggregate decrease of 13.3 percentage points, about 5.4 percentage points are explained by the sunk-cost component (KL ratio) as compared to 2.2 and 3.6 percentage points for firm size and profit per employee, respectively. Together these three variables explain more than $80 \%$ of the decrease in bribe incidence over time. This implies-in line with our analytical point of departure in Section II-a significant decline in the relative importance between 2005 and 2007 for bribe incidence of the ability/ willingness to pay (profits per employee), outside option (KL ratio), and exposure/visibility of firms (firm size). Moreover, a similar decline in relative 
importance for bribe behavior between 2005 and 2007 is observed for dealing with customs, inspections, and informality.

In appendix table A5, we also included province dummies in the BlinderOaxaca decomposition, as the province categorical variable potentially provides important information for understanding the decrease in bribe incidence over time. As highlighted in Yun (2008), the detailed decomposition results depend on the choice of the (omitted) base category for categorical regressors (only province included). The results in table A5 are nevertheless informative. We observe first that the detailed province coefficient effects and the intercept are indeed affected by the normalization. Moreover, in the usual decomposition (col. 2), we note a contribution to the overall bribe incidence decrease coming from rural regions. To illustrate, there is a decline in the relative importance for bribe incidence of being located in the "rural" provinces of Nghe An and Khanh Hoa. These are provinces that, according to the PCI (VNCI 2005, 2007), significantly improved corruption policies and actions taken against corrupt behavior between 2005 and 2007. Yet, opposite effects can be noted in the equally rural provinces of Quang Nam and Long An. Here the average bribe incidence increased (albeit from a low level). This is consistent with results in VNCI (2005, 2007), which document that Quang Nam and Long An did not experience considerable relative improvements in attitudes toward the traditional informal payments system during the period under study. ${ }^{20}$ Overall, the net contribution of rural provinces to the aggregate coefficients effect in the normalized equation (col. 3) is close to zero. The main contribution to the aggregate bribe incidence decrease therefore comes from the constant term (explaining approximately $30 \%$ of the decline). Accordingly, while provincial changes merit attention in some cases (and especially in rural areas), their overall aggregate impact seems limited. At the same time, it is encouraging that our results in this regard correspond well with the regional developments reflected in the PCI.

In sum, the nonlinear Blinder-Oaxaca decomposition suggests that the recent decline in bribe incidence observed among Vietnamese SMEs does not reflect changes in firm characteristics. The decrease would have occurred even without changes in observable firm characteristics. In fact, the entire bribe

\footnotetext{
20 The PCI (VNCI 2005, 2007) collects information at the provincial level regarding five different dimensions of corruption: (i) percentage of firms that believe that extra payments are a major obstacle to doing business, (ii) percentage of firms that felt that enterprises in their line of business were subject to bribe requests from provincial authorities, (iii) percentage of firms paying over $10 \%$ of their revenue in extra payments, (iv) government uses compliance with local regulations to extract rents (percentage strongly agree or agree), and (v) informal charges delivered the expected result (percentage usually or always).
} 
incidence decrease is explained by the coefficient effects, meaning that the decrease in bribe incidence between 2005 and 2007 is strictly related to behavioral changes among firms and regulators in relation to bribe provision. Arguably, the underlying driver behind these shifts includes the greater political commitment and improved law enforcement post-2005 alongside the increased media focus on punitive actions taken against corrupt individuals referred to in Section I. While in some cases these factors vary by province, we believe that they significantly increased the perception of both firms and public officials that they might get caught and would be punished in case of being corrupt. At a minimum this interpretation is entirely consistent with the observed behavioral change toward corruption and developments reflected in the PCI; but we cannot further disentangle the preference changes between bribe providers (firms) and bribe takers (public officials) with the data at hand.

\section{Conclusions}

The overall aim of this article has been to come to better grips with the nature, evolution, and potential impact of bribe-paying behavior among SMEs in Vietnam with a view to identifying relevant policy action. We have also suggested that, on balance, it would appear that the potential negative "distorting" impact of bribes might well be quite high because of their uncertain and random nature. Three sets of specific questions were raised: (i) What explains the incidence of bribe payments? (ii) Are amounts actually paid by firms driven by processes similar to bribe incidence? (iii) How can one explain the significant decline in bribing between 2005 and 2007? In trying to answer these questions, we are fortunate in having been involved in collecting over the past years a unique data set with relevant information on these issues covering 1,659 firms in 10 provinces of Vietnam. Three sets of insights have emerged.

First, bribe incidence among SMEs in Vietnam is closely associated with firm-level differences in sunk costs and ability to pay. More visible, relatively large, and formally registered firms are also more likely to provide informal payments. This leads us to conclude that the visibility effect seems to dominate the bribes-to-bide effect, and the implication is that the ongoing government push to combat bribes is well justified. This is underpinned by the fact that bribe incidence is significantly affected by some, although not by all, types of firm interaction with public officials. When the state acts as input supplier and provider of government assistance, bribe incidence clearly increases. The evidence is much less clear when the state is a customer of firms, when firms deal with customs, and when they are subject to inspection. This suggests that specific anticorruption government actions should be targeted toward 
activities in which the state is active in the first two areas, that is, as an input supplier and as a provider of assistance.

Second, we found that the magnitude of bribes is distinctly higher for firms that get preferential tax benefits and government contracts. This reveals that the processes that drive bribe incidence do seem to differ from those that drive the size of payments. This suggests that government action targeting government officials who receive bribes when they allocate government contracts and allow preferential tax benefits is likely to have a relatively high payoff as measured by the amount of bribes involved. In contrast, dealing with customs is neither a significant variable in explaining bribe incidence nor a key issue when focus is on the amounts paid.

Third, in explaining the significant decrease in bribe incidence between 2005 and 2007, the coefficients effect completely dominates the characteristics effect. This means that the bribe incidence decrease is related to behavioral changes on the part of firms or government regulators. Depending to some extent on provincial differences, these behavioral changes are, arguably, associated with ongoing general policy initiatives and increased political commitment to improve law enforcement alongside increased media focus on punitive actions against corruption. Continuing, deepening, and expanding regionally such general measures therefore seem to carry with them the promise of at least some success in the attempt to counteract corrupt behavior. 


\section{Appendix}

TABLE A1

SUMMARY STATISTICS LEGAL OWNERSHIP FORM, LOCATION, AND SECTOR

\begin{tabular}{|c|c|c|c|c|c|c|}
\hline & \multicolumn{2}{|c|}{ Total } & \multicolumn{2}{|c|}{2005} & \multicolumn{2}{|c|}{2007} \\
\hline & Mean & SD & Mean & SD & Mean & SD \\
\hline Household establishment/business & .758 & .428 & .764 & .425 & .752 & .432 \\
\hline Private (sole proprietorship) & .083 & .277 & .090 & .287 & .077 & .266 \\
\hline Partnership/collective/cooperative & .027 & .163 & .026 & .159 & .029 & .168 \\
\hline Limited-liability company & .121 & .327 & .112 & .315 & .131 & .338 \\
\hline Joint-stock company & .010 & .098 & .008 & .092 & .011 & .104 \\
\hline Hanoi & .081 & .273 & .081 & .273 & .081 & .273 \\
\hline Phu Tho & .108 & .310 & .108 & .310 & .108 & .310 \\
\hline Ha Tay & .172 & .378 & .172 & .378 & .172 & .378 \\
\hline Hai Phong & .063 & .244 & .063 & .244 & .063 & .244 \\
\hline Nghe An & .153 & .360 & .153 & .360 & .153 & .360 \\
\hline Quang Nam & .077 & .266 & .077 & .266 & .077 & .266 \\
\hline Khanh Hoa & .036 & .187 & .036 & .187 & .036 & .187 \\
\hline Lam Dong & .037 & .188 & .037 & .188 & .037 & .188 \\
\hline HCMC & .223 & .416 & .223 & .416 & .223 & .416 \\
\hline Long An & .051 & .219 & .051 & .219 & .051 & .219 \\
\hline Sector 1 & .294 & .456 & .295 & .456 & .293 & .455 \\
\hline Sector 2 & .002 & .049 & .000 & .000 & .005 & .069 \\
\hline Sector 3 & .038 & .191 & .036 & .187 & .040 & .196 \\
\hline Sector 4 & .030 & .170 & .028 & .166 & .031 & .174 \\
\hline Sector 5 & .018 & .133 & .016 & .124 & .020 & .142 \\
\hline Sector 6 & .109 & .311 & .092 & .289 & .126 & .332 \\
\hline Sector 7 & .024 & .154 & .025 & .155 & .024 & .153 \\
\hline Sector 8 & .020 & .139 & .020 & .142 & .019 & .135 \\
\hline Sector 9 & .002 & .046 & .004 & .065 & .000 & .000 \\
\hline Sector 10 & .014 & .119 & .012 & .109 & .017 & .129 \\
\hline Sector 11 & .054 & .225 & .054 & .225 & .054 & .225 \\
\hline Sector 12 & .065 & .247 & .066 & .248 & .064 & .246 \\
\hline Sector 13 & .008 & .091 & .007 & .085 & .010 & .098 \\
\hline Sector 14 & .172 & .378 & .173 & .378 & .171 & .377 \\
\hline Sector 15 & .029 & .168 & .030 & .171 & .028 & .166 \\
\hline Sector 16 & .006 & .079 & .005 & .069 & .008 & .088 \\
\hline Sector 17 & .004 & .062 & .005 & .069 & .003 & .055 \\
\hline Sector 18 & .108 & .310 & .132 & .339 & .083 & .276 \\
\hline Sector 19 & .002 & .046 & .001 & .025 & .004 & .060 \\
\hline Total observations & 3,318 & & 1,659 & & 1,659 & \\
\hline
\end{tabular}

Note. The sectors are defined as follows: (1) food products and beverages; (2) tobacco products; (3) textiles; (4) wearing apparel; (5) tanning and dressing leather; (6) wood and wood products; (7) paper and paper products; (8) publishing and printing; (9) refined petroleum; (10) chemical products; (11) rubber and plastic products; (12) nonmetallic mineral products; (13) basic metals; (14) fabricated metal products; (15) electrical and office machinery and other machinery and equipment; (16) vehicle parts; (17) medical, optical, and photo equipment, watches and clocks; (18) furniture, jewelry, musical instruments, sports equipment, and games and toys; (19) recycling.

This content downloaded from 212.146.036.034 on August 01, 2016 05:26:49 AM All use subject to University of Chicago Press Terms and Conditions (http://www.journals.uchicago.edu/t-and-c). 
TABLE A2

CORRELATION MATRIX INTERACTION WITH GOVERNMENT OFFICIALS

\begin{tabular}{lrrrrrr}
\hline & \multicolumn{1}{c}{$(1)$} & $(2)$ & $(3)$ & $(4)$ & (5) & (6) \\
\hline (1) State as customer & 1.0000 & & & & & \\
(2) State as input supplier & .1416 & 1.0000 & & & & \\
(3) Deal with customs (export/import) & .1036 & .0414 & 1.0000 & & & \\
(4) Received government assistance & .0846 & .0603 & .1174 & 1.0000 & & \\
(5) Inspected & .1248 & .0841 & .1253 & .0440 & 1.0000 & \\
(6) Not registered & -.1742 & -.1288 & -.1469 & -.0863 & -.4389 & 1.0000 \\
\hline
\end{tabular}

TABLE A3

BRIBE INCIDENCE WITH 2005 RIGHT-HAND-SIDE CONTROLS

\begin{tabular}{|c|c|c|c|c|}
\hline & \multicolumn{4}{|c|}{ Probit } \\
\hline & (1) & (2) & (3) & (4) \\
\hline Firm size (log employment) & $\begin{array}{l}.121^{\star \star \star} \\
(.010)\end{array}$ & $\begin{array}{l}.098^{\star \star \star} \\
(.013)\end{array}$ & $\begin{array}{l}.074^{\star \star \star} \\
(.012)\end{array}$ & $\begin{array}{l}.072^{\star \star \star} \\
(.014)\end{array}$ \\
\hline $\mathrm{KL}$ ratio $(\log )$ & $\begin{array}{l}.018^{\star} \\
(.010)\end{array}$ & $\begin{array}{c}.012 \\
(.010)\end{array}$ & $\begin{array}{c}.003 \\
(.010)\end{array}$ & $\begin{array}{c}.003 \\
(.010)\end{array}$ \\
\hline Profit/employee $(\log , t-1)$ & $\begin{array}{l}.027^{\star \star} \\
(.014)\end{array}$ & $\begin{array}{c}.017 \\
(.014)\end{array}$ & $\begin{array}{c}.011 \\
(.013)\end{array}$ & $\begin{array}{c}.016 \\
(.013)\end{array}$ \\
\hline State as customer & & & $\begin{array}{c}.017 \\
(.029)\end{array}$ & $\begin{array}{r}-.004 \\
(.029)\end{array}$ \\
\hline State as input supplier & & & $\begin{array}{c}.054 \\
(.038)\end{array}$ & $\begin{array}{c}.044 \\
(.039)\end{array}$ \\
\hline Deal with customs (export/import) & & & $\begin{array}{r}-.024 \\
(.039)\end{array}$ & $\begin{array}{r}-.039 \\
(.036)\end{array}$ \\
\hline Received government assistance & & & $\begin{array}{l}.079 \star \star \star \\
(.023)\end{array}$ & $\begin{array}{c}.030 \\
(.024)\end{array}$ \\
\hline Inspected & & & $\begin{array}{l}.097^{\star \star \star} \\
(.022)\end{array}$ & $\begin{array}{l}.082^{\star \star \star} \\
(.024)\end{array}$ \\
\hline Informal/not registered & & & $\begin{array}{c}-.160^{\star \star \star} \\
(.023)\end{array}$ & $\begin{array}{c}-.150 \star \star \star \\
(.024)\end{array}$ \\
\hline Legal structure dummies included & No & Yes & No & Yes \\
\hline Sector dummies included & No & Yes & No & Yes \\
\hline Province dummies included & No & Yes & No & Yes \\
\hline Observations & 1,659 & 1,659 & 1,659 & 1,659 \\
\hline Pseudo $R^{2}$ & .10 & .18 & .16 & .21 \\
\hline
\end{tabular}

Note. The dependent variable is bribe incidence; probit estimates, marginal effects. Standard errors (reported in parentheses) are heteroskedasticity robust.

* Significant at a $10 \%$ level.

$\star \star$ Significant at a $5 \%$ level.

$\star \star \star$ Significant at a $1 \%$ level.

This content downloaded from 212.146.036.034 on August 01, 2016 05:26:49 AM

All use subject to University of Chicago Press Terms and Conditions (http://www.journals.uchicago.edu/t-and-c). 
TABLE A4

BRIBE AMOUNT

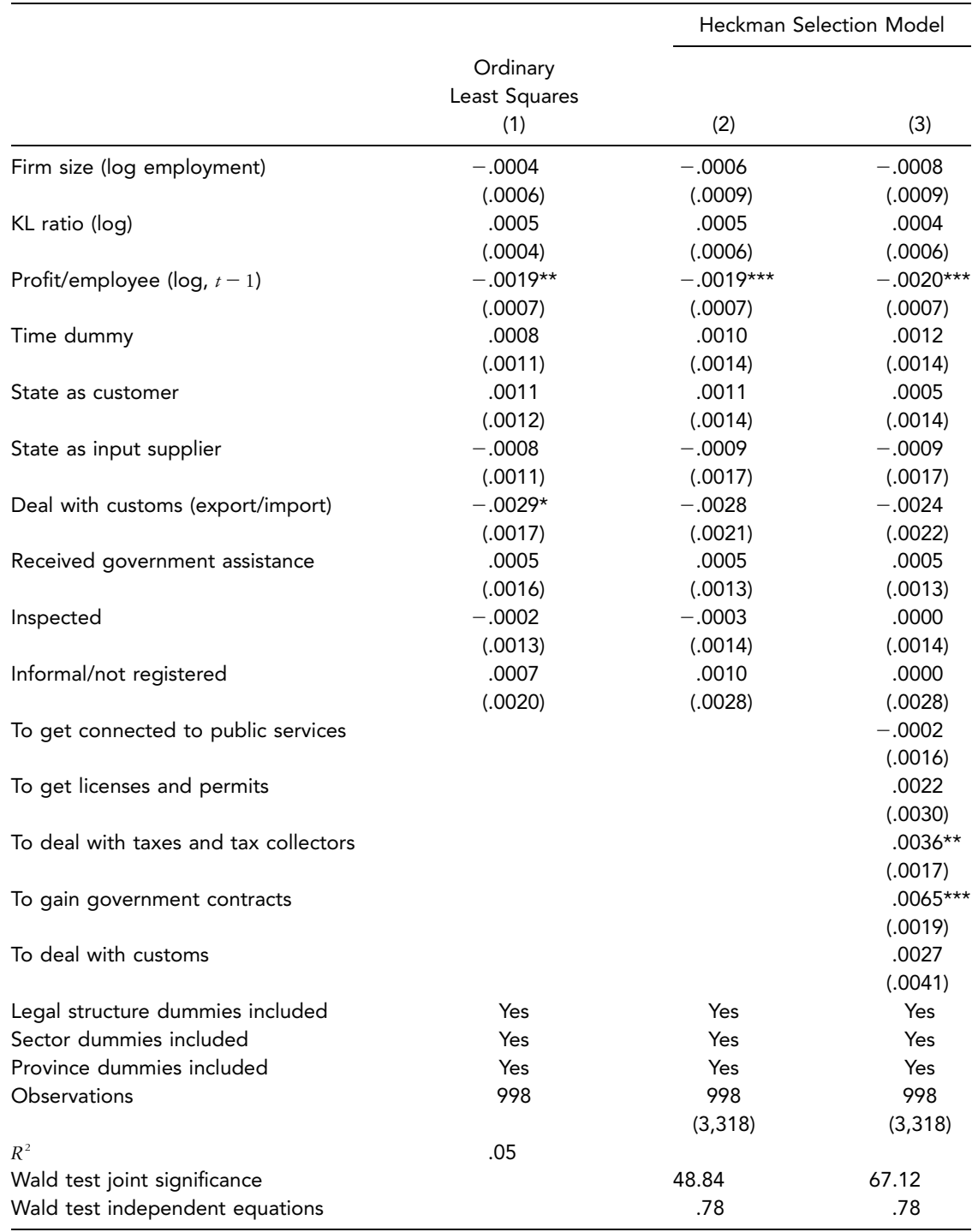

Note. The dependent variable is bribe amount (share of revenue). Standard errors are reported in parentheses. Column 1 includes only the 998 bribe-paying observations. In cols. 2 and 3, the Heckman selection model is identified on the basis of functional form. Column 3 includes a set of dummies for the purpose of bribe payments. The base is other, not well-identified purposes.

* Significant at a $10 \%$ level.

** Significant at a 5\% level.

$\star \star \star$ Significant at a $1 \%$ level.

This content downloaded from 212.146.036.034 on August 01, 2016 05:26:49 AM

All use subject to University of Chicago Press Terms and Conditions (http://www.journals.uchicago.edu/t-and-c). 
TABLE A5

BLINDER-OAXACA DECOMPOSITION INCLUDING PROVINCE DUMMIES

\begin{tabular}{|c|c|c|c|c|}
\hline & \multirow[b]{2}{*}{$\begin{array}{c}\text { Characteristics } \\
\text { Effect } \\
\text { (1) }\end{array}$} & \multicolumn{2}{|c|}{ Coefficients Effect } & \multirow[b]{2}{*}{$\begin{array}{c}\text { Interaction } \\
\text { Effect } \\
\text { (4) }\end{array}$} \\
\hline & & $\begin{array}{c}\text { Not } \\
\text { Normalized } \\
(2)\end{array}$ & $\begin{array}{c}\text { Normalized } \\
\text { (3) }\end{array}$ & \\
\hline Aggregate effect & $\begin{array}{c}.009 \\
(.010)\end{array}$ & $\begin{array}{r}-.133 \\
(.015)\end{array}$ & $\begin{array}{r}-.140 \\
(.015)\end{array}$ & $\begin{array}{r}-.012 \\
(.009)\end{array}$ \\
\hline Firm size (log employment) & $\begin{array}{r}-.009 \\
(.008)\end{array}$ & $\begin{array}{r}-.026 \\
(.035)\end{array}$ & $\begin{array}{r}-.026 \\
(.035)\end{array}$ & $\begin{array}{l}.001 \\
(.001)\end{array}$ \\
\hline $\mathrm{KL}$ ratio $(\log )$ & $\begin{array}{l}.009^{\star \star \star} \\
(.003)\end{array}$ & $\begin{array}{r}-.037 \\
(.057)\end{array}$ & $\begin{array}{r}-.037 \\
(.057)\end{array}$ & $\begin{array}{r}-.003 \\
(.005)\end{array}$ \\
\hline Profit/employee $(\log , t-1)$ & $\begin{array}{l}.013^{\star \star \star} \\
(.005)\end{array}$ & $\begin{array}{r}-.027 \\
(.042)\end{array}$ & $\begin{array}{r}-.027 \\
(.042)\end{array}$ & $\begin{array}{r}-.004 \\
(.006)\end{array}$ \\
\hline State as customer & $\begin{array}{c}.000 \\
(.000)\end{array}$ & $\begin{array}{c}.002 \\
(.006)\end{array}$ & $\begin{array}{c}.002 \\
(.006)\end{array}$ & $\begin{array}{c}.000 \\
(.000)\end{array}$ \\
\hline State as input supplier & $\begin{array}{c}.000 \\
(.001)\end{array}$ & $\begin{array}{c}.003 \\
(.004)\end{array}$ & $\begin{array}{l}.003 \\
(.004)\end{array}$ & $\begin{array}{c}.000 \\
(.000)\end{array}$ \\
\hline Deal with customs (export/import) & $\begin{array}{c}.000 \\
(.000)\end{array}$ & $\begin{array}{c}-.008^{\star \star} \\
(.004)\end{array}$ & $\begin{array}{c}-.008^{\star \star} \\
(.004)\end{array}$ & $\begin{array}{c}.001 \\
(.002)\end{array}$ \\
\hline Received government assistance & $\begin{array}{r}-.001 \\
(.002)\end{array}$ & $\begin{array}{c}.008 \\
(.010)\end{array}$ & $\begin{array}{c}.008 \\
(.010)\end{array}$ & $\begin{array}{r}-.002 \\
(.003)\end{array}$ \\
\hline Inspected & $\begin{array}{l}.014^{\star \star \star} \\
(.004)\end{array}$ & $\begin{array}{r}-.018 \\
(.016)\end{array}$ & $\begin{array}{r}-.018 \\
(.016)\end{array}$ & $\begin{array}{r}-.006 \\
(.005)\end{array}$ \\
\hline Informal/not registered & $\begin{array}{c}-.010^{\star} \\
(.005)\end{array}$ & $\begin{array}{c}.004 \\
(.013)\end{array}$ & $\begin{array}{l}.004 \\
(.013)\end{array}$ & $\begin{array}{c}.001 \\
(.003)\end{array}$ \\
\hline Hanoi & $\begin{array}{c}.000 \\
(.000)\end{array}$ & $\begin{array}{r}-.006 \\
(.004)\end{array}$ & $\begin{array}{r}-.001 \\
(.004)\end{array}$ & $\begin{array}{l}.000 \\
(.000)\end{array}$ \\
\hline Phu Tho & $\begin{array}{c}.000 \\
(.000)\end{array}$ & $\begin{array}{r}-.002 \\
(.007)\end{array}$ & $\begin{array}{l}.005 \\
(.005)\end{array}$ & $\begin{array}{l}.000 \\
(.001)\end{array}$ \\
\hline Ha Tay & $\begin{array}{c}.000 \\
(.001)\end{array}$ & $\begin{array}{c}-.021 \star \star \\
(.009)\end{array}$ & $\begin{array}{r}-.010 \\
(.008)\end{array}$ & $\begin{array}{l}.000 \\
(.001)\end{array}$ \\
\hline Hai Phong & $\begin{array}{c}.000 \\
(.001)\end{array}$ & $\begin{array}{r}-.004 \\
(.004)\end{array}$ & $\begin{array}{c}.000 \\
(.003)\end{array}$ & $\begin{array}{l}.000 \\
(.000)\end{array}$ \\
\hline Nghe An & $\begin{array}{c}.000 \\
(.002)\end{array}$ & $\begin{array}{c}-.031^{\star \star \star} \\
(.009)\end{array}$ & $\begin{array}{c}-.021^{\star \star \star} \\
(.007)\end{array}$ & $\begin{array}{c}.000 \\
(.002)\end{array}$ \\
\hline Quang Nam & $\begin{array}{c}.000 \\
(.002)\end{array}$ & $\begin{array}{l}.014^{\star \star \star} \\
(.005)\end{array}$ & $\begin{array}{l}.019 \star \star \star \\
(.005)\end{array}$ & $\begin{array}{c}.000 \\
(.003)\end{array}$ \\
\hline Khanh Hoa & $\begin{array}{c}.000 \\
(.002)\end{array}$ & $\begin{array}{c}-.012^{\star \star \star} \\
(.003)\end{array}$ & $\begin{array}{c}-.010^{\star \star \star} \\
(.003)\end{array}$ & $\begin{array}{c}.000 \\
(.002)\end{array}$ \\
\hline Lam Dong & $\begin{array}{c}.000 \\
(.000)\end{array}$ & $\begin{array}{r}-.006^{\star} \\
(.003)\end{array}$ & $\begin{array}{r}-.004 \\
(.003)\end{array}$ & $\begin{array}{c}.000 \\
(.001)\end{array}$ \\
\hline $\mathrm{HCMC}$ & $\begin{array}{c}.000 \\
(.002)\end{array}$ & & $\begin{array}{c}.014^{\star} \\
(.008)\end{array}$ & $\begin{array}{c}.000 \\
(.001)\end{array}$ \\
\hline Long An & $\begin{array}{c}.000 \\
(.001)\end{array}$ & $\begin{array}{l}.008^{\star \star} \\
(.004)\end{array}$ & $\begin{array}{l}.011^{\star \star \star} \\
(.003)\end{array}$ & $\begin{array}{c}.000 \\
(.002)\end{array}$ \\
\hline Constant & & $\begin{array}{l}.020 \\
(.094)\end{array}$ & $\begin{array}{r}-.043 \\
(.079)\end{array}$ & \\
\hline
\end{tabular}

Note. Detailed Blinder-Oaxaca decomposition with reference to col. 4 in table $5 ; 3,318$ observations. Standard errors are reported in parentheses. HCMC is the base category.

* Significant at a $10 \%$ level.

** Significant at a $5 \%$ level.

$\star \star \star$ Significant at a $1 \%$ level.

This content downloaded from 212.146.036.034 on August 01, 2016 05:26:49 AM All use subject to University of Chicago Press Terms and Conditions (http://www.journals.uchicago.edu/t-and-c). 


\section{References}

CIEM (Central Institute for Economic Management). 2007. Characteristics of the Vietnamese Business Environment: Evidence from a SME Survey in 2005. Hanoi: CIEM.

- 2009. "Characteristics of the Vietnamese Business Environment: Evidence from a SME Survey in 2007." Hanoi: CIEM.

Clarke, G. R. G., and L. C. Xu. 2004. "Privatization, Competition and Corruption: How Characteristics of Bribe Takers and Payers Affect Bribes to Utilities." Lournal of Public Economics 88:2067-97.

Dabla-Norris, E., M. Gradstein, and G. Inchauste. 2008. "What Causes Firms to Hide Output? The Determinants of Informality." Iournal of Development Economics $85: 1-27$.

Farlie, R. W. 2005. "An Extension of the Blinder-Oaxaca Decomposition Technique to Logit and Probit Models." Journal of Economic and Social Measurement 30:30516.

Fisman, R., and J. Svensson. 2007. "Are Corruption and Taxation Really Harmful to Growth? Firm Level Evidence." Iournal of Development Economics 83:63-75.

General Statistics Office. 2004. Results of Establishment Census of Vietnam 2002. Vol. 2, Business Establishments. Hanoi: Statistical Publishing House.

Hansen, H., J. Rand, and F. Tarp. 2009. "Enterprise Growth and Survival in Vietnam: Did Government Support Matter?”. Journal of Development Studies 45, no. 7:104869.

Jann, B. 2008. "A Stata Implementation of the Blinder-Oaxaca Decomposition." Sociology Working Paper no. 5, Swiss Federal Institute of Technology, Zurich.

McKensie, D., and Y. S. Sakho. 2010. "Does It Pay to Register for Taxes? The Impact of Formality on Firm Profitability." Iournal of Development Economics 91: $15-24$.

McKinley, C. 2008. "Can a State-Owned Media Effectively Monitor Corruption? A Study of Vietnam's Printed Press." Asian Journal of Public Affairs 2, no. 1:12-38.

Nguyen, B. T., J. W. Albrecht, S. B. Vroman, and M. D. Westbrook. 2007. “A Quantile Regression Decomposition of Urban-Rural Inequality in Vietnam.” Journal of Development Economics 83:466-90.

Sato, Y. 2009. "How to Deal with Corruption in Transitional and Developing Economies: A Vietnamese Case Study." Iournal of Financial Crime 16, no. 3:220-28.

Segon, M., and C. Booth. 2010. "Managerial Perspectives of Bribery and Corruption in Vietnam." International Review of Business Research Papers 6, no. 1:574-89.

Shleifer, A., and R. W. Vishny. 1993. "Corruption." Ouarterly Journal of Economics 108:599-617.

- 1994. "Politicians and Firms." Quarterly Journal of Economics 109:995-1025.

Sinning, M., M. Hahn, and T. K. Bauer. 2008. "The Blinder-Oaxaca Decomposition for Non-linear Regression Models.” Stata Journal 4:480-92.

Svensson, J. 2003. "Who Must Pay Bribes and How Much? Evidence from a Cross Section of Firms." Ouarterly Journal of Economics 118:207-30.

Tenev, S., A. Carlier, O. Chaudry, and Q.-T. Nguyen. 2003. "Informality and the Playing Field in Vietnam's Business Sector." Photocopy, International Finance Corp., World Bank, and Mekong Project Development Facility, Washington, DC. VNCI (Vietnam Competitiveness Initiative). 2005. "The Vietnam Provincial Com- 
petitiveness Index 2005: Measuring Economic Governance for Private Sector Development." VNCI Policy Paper no. 4, Vietnam Chamber of Commerce and Industry and US Agency for International Development's Vietnam Competitiveness Initiative, Hanoi.

2007. "The Vietnam Provincial Competitiveness Index 2007: Measuring Economic Governance for Private Sector Development." VCNI Policy Paper no. 12, Vietnam Chamber of Commerce and Industry and US Agency for International Development's Vietnam Competitiveness Initiative, Hanoi.

2008. "The Vietnam Provincial Competitiveness Index 2008: Measuring Economic Governance for Private Sector Development.” VNCI Policy Paper no. 13, Vietnam Chamber of Commerce and Industry and US Agency for International Development's Vietnam Competitiveness Initiative, Hanoi.

Wu, X. 2009. "Determinants of Bribery in Asian Firms: Evidence from the World Business Environment Survey." Iournal of Business Ethics 87:75-88.

Yun, M.-S. 2008. "Identification Problem and Detailed Oaxaca Decomposition: A General Solution and Inference." Journal of Economic and Social Measurement 33:2738. 